\title{
The burning building
}

\author{
Fiona Godlee editor in chief
}

The BMJ

With the covid-19 pandemic, we have entered extraordinary times, when some things are known but many more are not and where decisions must be made nonetheless.

The UK government's recent actions (doi:10.1136/bmj.m1089) bring the country more in line with its European neighbours. Public health has now been prioritised over the economy. The change of heart seems to have been in response both to international criticism of its earlier laissez faire approach and to a new modelling study suggesting that the NHS would not cope unless more was done to curb the spread of the virus. Publication of this study means that we at last have some of the evidence on which the government's decisions have been based. If we are to trust the science, we need more, indeed all of it. Academics who are holding back their data should be encouraged to publish their work as preprints as soon as possible.

Governments must achieve a fine balancing act, as England's chief medical officer Chris Whitty has made clear. Although the new measures should reduce demand on the health system, they are also decimating supply as staff stay at home because they or their family have symptoms. There is an urgent need for increased capacity to test frontline healthcare workers, especially a quick serological test to show who has had the infection and is immune and therefore able to safely return to work. Several preprints hint at this technology being available soon (doi:10.1101/2020.02.27.20028787, doi:10.1101/2020.03. 06.20031856, doi:10.1101/2020.02.20.20025999, doi:10.1101/ 2020.02.22.20026617, doi:10.1101/2020.03.04.20030916).

Meanwhile, we need to take special care of those on the front line. Junior doctors need leadership and lockers to put their home clothes in. Seniors need resources to help them protect and support their teams. GPs need clear guidance on how best to manage patients as they shift to delivering more care by phone and video. Intensivists need support to make difficult decisions about which critically ill patients to prioritise. All staff need compassion, food, and places to rest and recover (doi:10.1136/ bmj.m1087).

Healthcare is already changing as a result of covid-19 in some positive ways: the public is at last learning self-management; hand washing is in; technology is being embraced; phone and video are replacing face to face consultations; there are drive through clinics; people are working across traditional divisions of primary, secondary, and tertiary care and volunteering to be deployed from quieter specialties or retirement into areas of need. As Matt Morgan writes, "Difficult problems that have slept on in-trays for years are getting solved" (doi:10.1136/bmj. m1062)

But we are all scared-for our colleagues, our families, and ourselves. A few days ago in Spain, people hung out of their windows to applaud their doctors and nurses, who emerged blinking into the air before quickly returning to the tasks at hand. For them and their colleagues around the world, there may be more certainty as the weeks progress, but as Shreena Unadkat and Michael Farquhar say, this is a marathon not a sprint (http://bit.ly/3a1mRUE). Doctors and nurses are akin to firefighters running into rather than away from the burning building. Only if we and our governments give them our unstinting support will we as a world get through this crisis.

Competing interests: BMJ is a partner in medRxiv preprint server (www.medrxiv. org)

Published by the BMJ Publishing Group Limited. For permission to use (where not already granted under a licence) please go to http://group.bmj.com/group/rights-licensing/ permissions 